\title{
アコースティック・エミッションを用いた炭素鋼レーザ焼入れ の観察
}

\author{
${ }^{1}$ 阿南工業高等専門学校創造技術工学科 \\ 2 阿南工業高等専門学校専攻科構造設計工学専攻 \\ J. Japan Inst. Met. Mater. Vol. 84, No. 11 (2020), pp. 335-343 \\ (C) 2020 The Japan Institute of Metals and Materials
}

安田武司 ${ }^{1}$ 魁生 誠 ${ }^{2, *}$ 西本 浩司 ${ }^{1}$ 奥本 良 博 ${ }^{1}$

\section{Monitoring of Laser Quenching of the Carbon Steel by Acoustic Emission}

Takeshi Yasuda $^{1}$, Makoto Kaisho ${ }^{2, *}$, Koji Nishimoto ${ }^{1}$ and Yoshihiro Okumoto ${ }^{1}$

${ }^{1}$ Department of Creative Technology Engineering, National Institute of Technology, Anan College, Anan 774-0017
${ }^{2}$ Structure Design Engineering, Advanced Course, National Institute of Technology, Anan College, Anan 774-0017

This study aims to establish fundamental knowledge for online non-destructive inspection in the laser quenching process utilizing acoustic emission. Acoustic emission is the transient elastic wave phenomenon due to release of strain energy in a solid material. And it is well known that the martensitic transformation can induce the acoustic emission. In this study, the acoustic emission monitoring of martensitic transformation during laser quenching experiment was conducted with the chromium molybdenum carbon steel (SCM440 in Japanese Industrial Standards) as the specimen. The experiment was carried out with seven kinds of laser irradiation power for different volume generation of heat-affected zone. After experiment, the martensite structure was confirmed at the heat-affected zone and the volume of the martensite structure within the zone was estimated. Only the specimen irradiated by the lowest laser power had no martensite structure. The acoustic emission waves were analyzed using parameters that showed the generation time duration and scale of source phenomenon. As a result, the relationship between the volume of martensite structure and information of acoustic emission was positive. It was suggested that the acoustic emission monitoring have application for the online non-destructive inspection for the laser quenching process.

[doi:10.2320/jinstmet.J2020024]

(Received May 29, 2020; Accepted August 4, 2020; Published September 11, 2020)

Keywords: laser quenching, acoustic emission, AE (acoustic emission), martensitic transformation, non-destructive inspection, online inspection, carbon steel

\section{1. 諸言}

近年，レーザ技術の工業的応用が注目されており，その実 用は材料の除去加工，溶融接合，あるいは表面改質など多岐 にわたる ${ }^{1,2)}$. 表面改質においては，炭素鋼へのレーザ照射 による局部加熱および炭素鋼の自己冷却能力による急冷から 表面焼入れが得られるといったレーザ焼入れがある。これに は，形状が複雑な製品であっても必要な部分にのみレーザを 照射し，表面焼入れを施すことができるといった利点があ る。焼入れ製品に対しては指定された基準を満たしている か, 工程における検査が必要とされる，通常，焼入れ製品の 検査では, 抜き取り検査対象となった製品について, 焼入れ 部の断面をとり, 研磨とエッチングを施し, その後, 顕微鏡 による断面観察から焼入れ後の熱影響部 (heat affected zone, HAZ)に生成しているマルテンサイト組織などを確認し，さ らに硬さ試験を実施して硬化層の品質が保証される。よっ

\footnotetext{
* 阿南工業高等専門学校専攻科生, 現在：豊橋技術科学大学大学 院生 (Advanced Course Student, National Institute of Technology, Anan College, Present address: Graduate Student, Toyohashi University of Technology)
}

て，生産工程には検査に対する時間と労力がかかり，また， 全数検査は困難であると考えられる．表面焼入れ製品を対象 として, 超音波や磁気, 渦電流, そして電位差による方法か ら硬化層深さを確認する非破壊検査法がある ${ }^{3)}$ 。ただし, こ れらの方法はプローブの方式や形状の制限から，レーザ焼入 れが用いられるような複雑形状の製品を検査することが困難 となる場合も考えられる.

本研究では, 固体が外力を受けて変形もしくは破壊する際 に, それまで固体内部に蓄えられていた弾性エネルギーが弾 性波となって周囲に放出される現象である,「アコース ティック・エミッション (acoustic emission, AE) 」4) の利用に 着目した。炭素鋼の焼入れによる硬化は，オーステナイト状 態からの急冷によるマルテンサイト変態によって生成したマ ルテンサイト組織によるものであり，このマルテンサイト変 態は格子ひずみを伴う無拡散格子変態であることから，この 変態中にも $\mathrm{AE}$ が発生することがよく知られている5). 特 に, $\mathrm{AE}$ はその発生源から固体内部を伝播し, やがて固体の 表面まで届く弾性波であるため, $\mathrm{AE}$ 発生源となった現象を 非破壊的かつその場観察することが可能であり，また，検出 方法を工夫すれば複雑な形状の製品検査にも適用できる可能 性がある，そこで，本研究では，炭素鋼のレーザ焼入れに伴 
うマルテンサイト変態によって発生した $\mathrm{AE}$ を検出し, 試料 に生成した HAZすなわちマルテンサイト組織の体積と比較 することで, レーザ焼入れの非破壊その場検査法を検討する ことを目的とした。この非破壊その場検査法を検討すること ができれば, 製品単価が比較的高いと考えられるレーザ焼入 れ製品について, 生産工程における従来方式の抜き取り検査 数の削減, 破壊検査にかかる時間, 労力などの削減, そし て, 非破壊その場検査法による全数検査の実現可能性につな げることができる。

関係する先行研究として, YAG レーザによる炭素鋼への 表面焼入れと焼入れ状態の評価に $\mathrm{AE}$ 観察を適用した研究が 発表されており, 結論は「燒入れ部分の硬さを非破壊的に検 査する方法として有効である」と述べられている ${ }^{6,7)}$. しか し，レーザ焼入れ後に得られたマルテンサイト組織の体積な どと $\mathrm{AE}$ の挙動との関係性については明言に至っていない. よって本研究では，レーザ焼入れによって生成したマルテン サイト組織の体積と観察された $\mathrm{AE}$ の関係について調査する ことを目的とした．得られた知見を先行研究に付加すること ができれば， AEを用いたレーザ焼入れのための非破壊その 場検査法をより価值の高いものとして提案することができ る.これとは別に, 過去に炭素鋼のスポット溶接部のマルテ ンサイト組織生成について, $\mathrm{AE}$ 観察を実施した研究が発表 されている ${ }^{8)}$. 炭素鋼の溶接継手部における溶接後のマルテ ンサイト組織の生成は，溶接継手部の延性低下をまねく恐れ があるため， AE などを利用して観察することは有用である と考えられる。近年ではレーザ溶接技術が発展しているが, レーザ溶接継手部のマルテンサイト組織の生成に $\mathrm{AE}$ 観察を 用いた事例は少なく，本研究の成果によっては，レーザ溶接 中のマルテンサイト変態に対する非破壊その場検査法の提案 も期待できる.

以上の経緯から, 本研究では, ファイバーレーザを用いた クロムモリブデン鋼への円形状レーザ焼入れ実験を数種類の レーザ出力条件のもとで実施し, 各条件での実験においてマ ルテンサイト変態に伴う AEを観察した。試料の HAZ, す なわちマルテンサイト組織の生成を確認し, その推定体積を 算出した上で，選定したパラメータでまとめた $\mathrm{AE}$ のデータ と比較，検討したのでこれを報告する.

\section{2. 実 験 方 法}

\section{1 供試材料}

本研究では, 供試材料として焼入れ性が良いクロムモリブ デン鋼 (JIS G 4053 機械構造用合金鋼鋼材 SCM440) ${ }^{9)}$ を用意 した. $830^{\circ} \mathrm{C} に て ~ 1 \mathrm{~h}$ 保持後, 空冷した焼ならし材であり, 初期組織はフェライト・パーライトである. Table 1 に SCM440の化学組成(規格值) と文献 10) に掲載された $\mathrm{SCM} 440$ の CCT 図から読み取った $\mathrm{A}_{\mathrm{c} 3}, \mathrm{~A}_{\mathrm{cl}}, \mathrm{M}_{\mathrm{s}}$ の各変態 点, および上部臨界冷却速度を示す。例えば, 焼入れの急冷 時では $5 \mathrm{~s}$ 以内に $\mathrm{A}_{\mathrm{c} 3}$ 点から $\mathrm{M}_{\mathrm{s}}$ 点に到達すれば, マルテン サイト変態のみ発生する。レーザ焼入れおよび $\mathrm{AE}$ 検出実験 に際し, 寸法を Fig. 1 に示すとおり縦 $20 \mathrm{~mm}$, 横 $20 \mathrm{~mm}$, 厚 さ $12 \mathrm{~mm}$ に機械加工して試料とした。 なお，試料に $\mathrm{AE}$
Table 1 Chemical composition, transformation temperature ${ }^{10)}$ and critical cooling rate ${ }^{10)}$ of SCM440 used as the specimen.

\begin{tabular}{ll||lc}
\hline Substances & $\begin{array}{l}\text { Compositions } \\
(\text { mass\%) }\end{array}$ & \multicolumn{2}{|l}{$\begin{array}{l}\text { Transformation } \\
\text { temperature }\left({ }^{\circ} \mathrm{C}\right)^{10)}\end{array}$} \\
\hline $\mathrm{C}$ & $0.38 \sim 0.43$ & $\mathrm{~A}_{\mathrm{c} 3}$ & 772 \\
$\mathrm{Si}$ & $0.15 \sim 0.35$ & $\mathrm{~A}_{\mathrm{c} 1}$ & 728 \\
$\mathrm{Mn}$ & $0.60 \sim 0.90$ & $\mathrm{M}_{\mathrm{s}}$ & 363 \\
$\mathrm{P}$ & $\geqq 0.030$ & \\
$\mathrm{~S}$ & $\geqq 0.030$ & Critical cooling \\
$\mathrm{Ni}$ & $\geqq 0.25$ & rate $(\mathrm{K} / \mathrm{s})^{10)}$ \\
$\mathrm{Cr}$ & $0.90 \sim 1.20$ & \multicolumn{2}{|c}{82} \\
$\mathrm{Mo}$ & $0.15 \sim 0.30$ & \\
$\mathrm{Fe}$ & $\mathrm{Bal}$. & \\
\hline
\end{tabular}

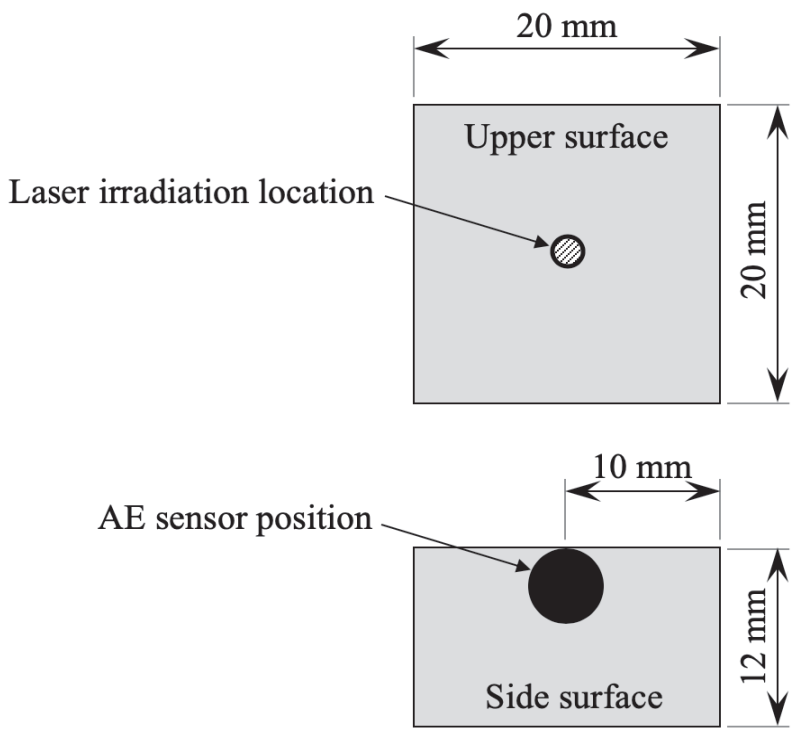

Fig. 1 Size of specimen, location of laser irradiation and AE sensor position.

ンサが密着するよう， $\mathrm{AE}$ センサ取り付け面となる側面には エメリ紙およびバフ研磨によって鏡面とした。

\section{2 レーザ焼入れおよび $\mathrm{AE}$ 検出実験}

Fig. 2 にレーザ焼入れおよび $\mathrm{AE}$ 検出実験の概要図を示す. 本実験では円形状ファイバーレーザを用いて試料に局所加熱 を与え, 加熱終了以降の試料自己冷却能力による急冷から焼 入れを行った，実験は $27.0^{\circ} \mathrm{C}$ の大気中にて行い, 試料は縦 $150 \mathrm{~mm}$, 横 $150 \mathrm{~mm}$, 厚さ $4.0 \mathrm{~mm}$ のアルミニウム合金 (A5052)製ステージに設置した．試料におけるレーザ照射位 置は, Fig. 1 のとおり上面の中心とし, 円形状ファイバー レーザは焦点外し距離を $+34 \mathrm{~mm}$ として $3 \mathrm{~s}$ 照射, その後即 座に自動停止する設定とした。レーザ出力は $275 \mathrm{~W}$ を最大 とし， $275 \mathrm{~W}$ から $260 \mathrm{~W}$ までは $5 \mathrm{~W}$ 毎に, $260 \mathrm{~W}$ から 230 $\mathrm{W}$ までは $10 \mathrm{~W}$ 毎に減少させた。本研究はレーザを走査させ ない局所加熱および焼入れとなるが，レーザを走査させて試 料の任意領域を加熱し焼入れを施す場合についても今後検討 
する必要があると考えている。なお、レーザによる試料の加 熱スポットの最高到達温度 $T_{\max }$ およびレーザ停止後 $\mathrm{M}_{\mathrm{s}}$ 点ま で到達する時間 $\Delta t$ を把握するため, CAEソフトウェアを用 いた熱伝導解析を行った. Table 2 にこれにより推定された 值を示す．解析モデルには試料である SCM440の他に，ア ルミニウム合金製ステージも含めた

実験中に発生した AE は, Fig. 1 のように試料側面の上端 中央に取り付けた $\mathrm{AE} セ ン サ に よ り$ 検出した。直径 $5 \mathrm{~mm}$ の $\mathrm{AE}$ センサ受信面は接触媒質に高真空グリースを用いて試料 に密着させ，バネによって押し付け荷重が一定となるクリッ プ状器具により確実に固定した. Fig. 2 に示すように, $\mathrm{AE}$ センサ $(100 \mathrm{kHz}-10 \mathrm{MHz}$ 広帯域型)により検出された $\mathrm{AE}$ 波 信号はプリアンプによって $40 \mathrm{~dB}$ 増幅し, サンプリング周波 数 $1 \mathrm{MHz}$ にて高速デジタルレコーダに記録した。本研究で は $\mathrm{AE}$ 信号と環境ノイズの SN 比が比較的低くみられたた め，実験時はしきい值を設けず，レーザ照射開始から停止の $3 \mathrm{~s}$, さらにその後の焼入れ過程 $1 \mathrm{~s}$, 以上合計 $4 \mathrm{~s}$ について $\mathrm{AE}$ と環境ノイズを一括して高速デジタルレコーダのメモリ に取り込み, 実験後に改めて $\mathrm{AE}$ のデータを処理することと

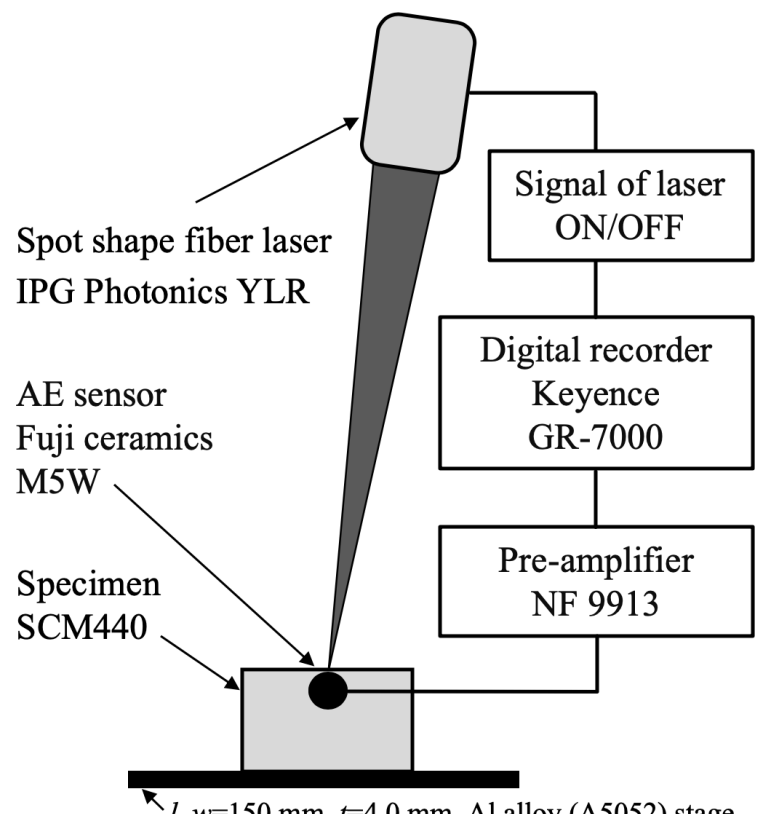

Fig. 2 Experimental setup for laser quenching and AE monitoring.

Table 2 Simulated maximum temperature and cooling time to $M_{s}$ temperature of heated surface spot.

\begin{tabular}{lll}
\hline $\begin{array}{l}\text { Laser power } \\
P / \mathrm{W}\end{array}$ & $\begin{array}{l}\text { Max. temp., } \\
T_{\max } /{ }^{\circ} \mathrm{C}\end{array}$ & $\begin{array}{l}\text { Cooling Time } \\
\text { to } \mathrm{M}_{\mathrm{s},} \Delta t / \mathrm{ms}\end{array}$ \\
\hline 275 & 845 & 32 \\
270 & 828 & 30 \\
265 & 807 & 29 \\
260 & 786 & 28 \\
250 & 758 & 27 \\
240 & 712 & 24 \\
230 & 639 & 19 \\
\hline
\end{tabular}

した。また，高速デジタルレコーダの別チャンネルにはレー ザ照射および停止に伴う機器信号を同時に記録した。

\section{3 試料観察および硬さ試験}

レーザ焼入れ実験後，試料上面に生じたレーザ加熱跡であ る加熱スポットの外観観察およびスポット中心を通る試料縦 断面(試料厚さ方向断面)の共焦点レーザ顕微鏡観察, そして HAZ 内部の走査型電子顕微鏡観察を行った．試料縦断面に ついては，あらかじめ試料を長さ $10 \mathrm{~mm}$ より僅かに大きく なるよう精密切断機によって切断し, 光学顕微鏡により試料 上面から見たスポットの半径を測定，その值を参考として平 面研削盤によりスポットが正確に半円となるよう加工した. その後, この断面をエメリ紙およびバフ研磨によって鏡面と し，3\%ナイタール液によりエッチングを施して組織観察を 行った.レーザ焼入れによる HAZ は Fig. 3 のようにこの試 料縦断面内に弓形状に現れるため, HAZ は球冠形状と考え られる。よって, 本研究では組織観察の際に共焦点レーザ顕 微鏡の測定機能を用いて弓形状に観察された HAZ の最大幅 $2 a$ と最大深さ $h$ を測り, 球冠体積の算出式,

$$
V=\frac{1}{6} \pi h\left(3 a^{2}+h^{2}\right)
$$

からこの HAZ の推定体積を求めた

組織観察の後, HAZ 中心および HAZより十分に離れた部 分において，マイクロビッカース硬さ試験を行った。

\section{4 本研究において用いた $\mathrm{AE}$ パラメータ}

本研究では，観察された環境ノイズを含む $\mathrm{AE}$ のデー夕を 実験後に高速デジタルレコーダからパーソナルコンピュータ に移動させ，オフラインにて分析を行った。詳細は次章にて 述べるが，レーザ照射停止後の焼入れ過程における $\mathrm{AE} に$ 着 目している。しきい值をノイズレベルに設定し， $\mathrm{AE}$ パラ メータとして AE カウント数 ${ }^{11,12)}$ を用いた集計を行った. AE カウント数とは, Fig. 4(a)に示すように AEの振幅がし きい值を超えた回数のことを言い，この累積数を時間軸でま とめると AE 発生現象の頻度を Fig. 4(b)のように概ね把握で きる。この $\mathrm{AE}$ カウント累積数の推移を参考として $\mathrm{AE}$ の持 続時間を特定し，この時間帯の $\mathrm{AE}$ について実効値 ${ }^{12)}$ を算出 した.この実効值は RMS (Root Mean Square) 值とも呼ばれ, $\mathrm{AE}$ を $f_{(\mathrm{t})}, \mathrm{AE}$ の持続時間を $T=t_{1}-t_{0}$ とすると次式,

$$
V_{R M S}=\sqrt{\frac{1}{T} \int_{t_{0}}^{t_{1}}\left[f_{(t)}\right]^{2} \mathrm{~d} t}
$$

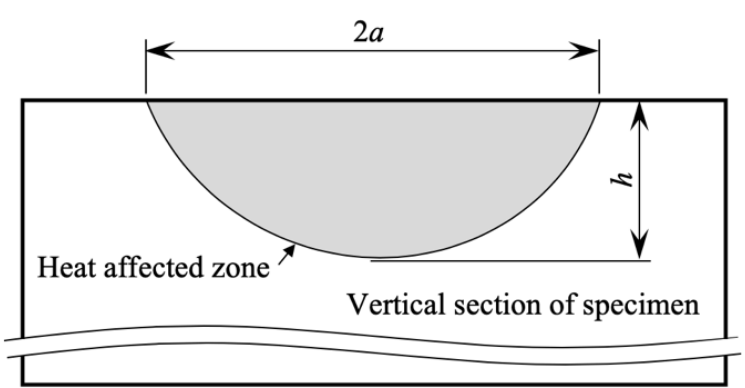

Fig. 3 Estimation of HAZ in vertical section of laser quenched specimen. 
で与えられる。 RMS 值は $\mathrm{AE}$ 発生源の程度すなわちエネル ギーを把握することのできる AE パラメータである.

\section{3. 実験結果と考察}

\section{1 レーザ焼入れ部表面および断面の観察と HAZ の体積}

Fig. 5 に示すように，レーザ焼入れ実験を行った試料上面 にはレーザ加熱跡であるスポットが生じた．各レーザ出力の スポット外観を目視検査し比較したところ, 出力 $240 \mathrm{~W}$ と $230 \mathrm{~W}$ の様相差は明らかであるが，それ以外については局所 加熱の程度の差異が $5 \mathrm{~W}$ あるいは $10 \mathrm{~W}$ のレーザ出力差にお いて把握しづらい.ただし，光学顕微鏡による測定からは, レーザ出力が大きいほどスポット直径が大きいことが確認さ れた. Fig. 6 は，2.3節にて述べた方法に従って行ったス

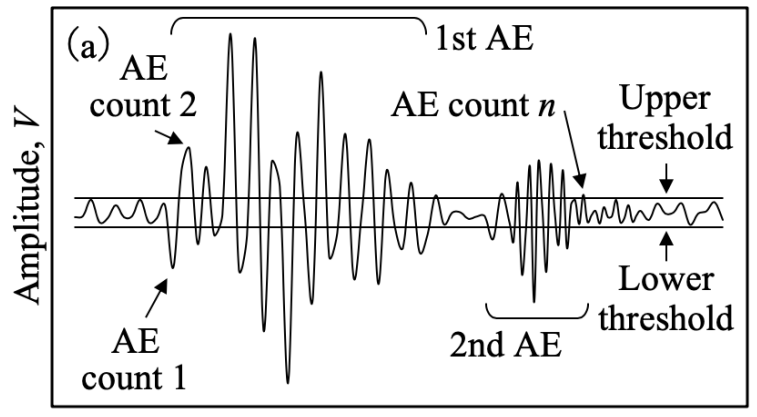

Time, $t$

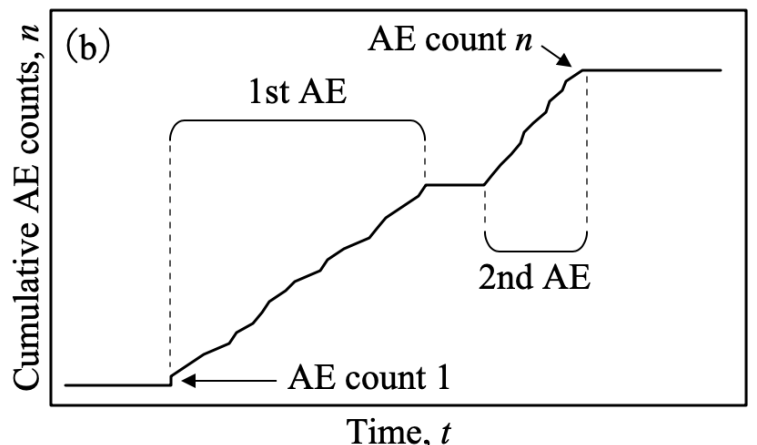

Fig. 4 Example of threshold, AE count and cumulative AE counts. (a) $\mathrm{AE}$ wave, threshold and $\mathrm{AE}$ count, (b) cumulative AE counts.
ポット中心を通る試料縦断面の共焦点レーザ顕微鏡観察およ び HAZ 内部の走査型電子顕微鏡による組織観察の結果であ る. 出力 $230 \mathrm{~W}$ を除き, 試料縦断面内にはあらかじめ Fig. 3 に示したような弓形状にHAZが現れた，そのため，HAZは 球冠形状と考えられる.また, レーザ出力が高いほど, HAZ の最大幅およびその深さも大きくなっていることが確 認できた. Table 3 に HAZ が観察された出力 $230 \mathrm{~W}$ 以外の試 料について, HAZの最大幅および最大深さを式 (1 )に代入 して算出した推定体積をまとめた。レーザ出力が大きいほど HAZ の体積は大きいことが確認できる.

Fig. 6 右側には HAZ 内部の走査型電子顕微鏡観察を行っ た結果を示している. Table 1 に記した SCM440の $\mathrm{A}_{\mathrm{c} 3}$ 点, $\mathrm{A}_{\mathrm{c} 1}$ 点, $\mathrm{M}_{\mathrm{s}}$ 点の温度と上部臨界冷却速度, そして Table 2 に 記した熱伝導解析による加熱スポットの最高到達温度および レーザ停止後 $\mathrm{M}_{\mathrm{S}}$ 点まで到達する時間の推定值から，レーザ 出力 $260 \mathrm{~W}$ 以上ではオーステナイトから, $250 \mathrm{~W}$ ではフェ

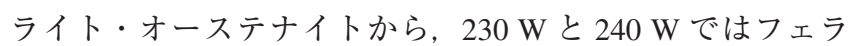
イト・パーライトからそれぞれ急冷がなされると考えられる ため, $230 \mathrm{~W}$ と $240 \mathrm{~W}$ ではマルテンサイト組織が生成しな いと予想されたが, 結果では $240 \mathrm{~W}$ 以上のレーザ出力にお いて針状のマルテンサイト組織が確認された。 また，レーザ 出力 $250 \mathrm{~W}$ の観察では, 加熱時にオーステナイト化に至ら なかったフェライトが確認されなかった。 これに加えて， $240 \mathrm{~W}$ でもマルテンサイト組織が観察されていることから, 実験では熱伝導解析による推定值よりも高い温度まで加熱さ れていたことが考えられる。レーザ光の反射, 吸収は材料の 表面性状の影響を受けるため, 実験と熱伝導解析の結果に差 異が出たと考えられる．なお，レーザ出力 $275 〜 240 \mathrm{~W}$ の試 料 HAZ 外の領域および $230 \mathrm{~W}$ の試料の試料縦断面からは, フェライト・パーライト組織が確認された.

\section{2 レーザ焼入れ部断面のビッカース硬さ}

Table 4 に, 各レーザ出力の試料の HAZ 中心および HAZ より十分に離れた部分にて行ったマイクロビッカース硬さ試 験の結果を示す。ただし, 出力 $230 \mathrm{~W}$ の試料は HAZ が確認 されなかったため，スポット直下部分での実施に置き換え

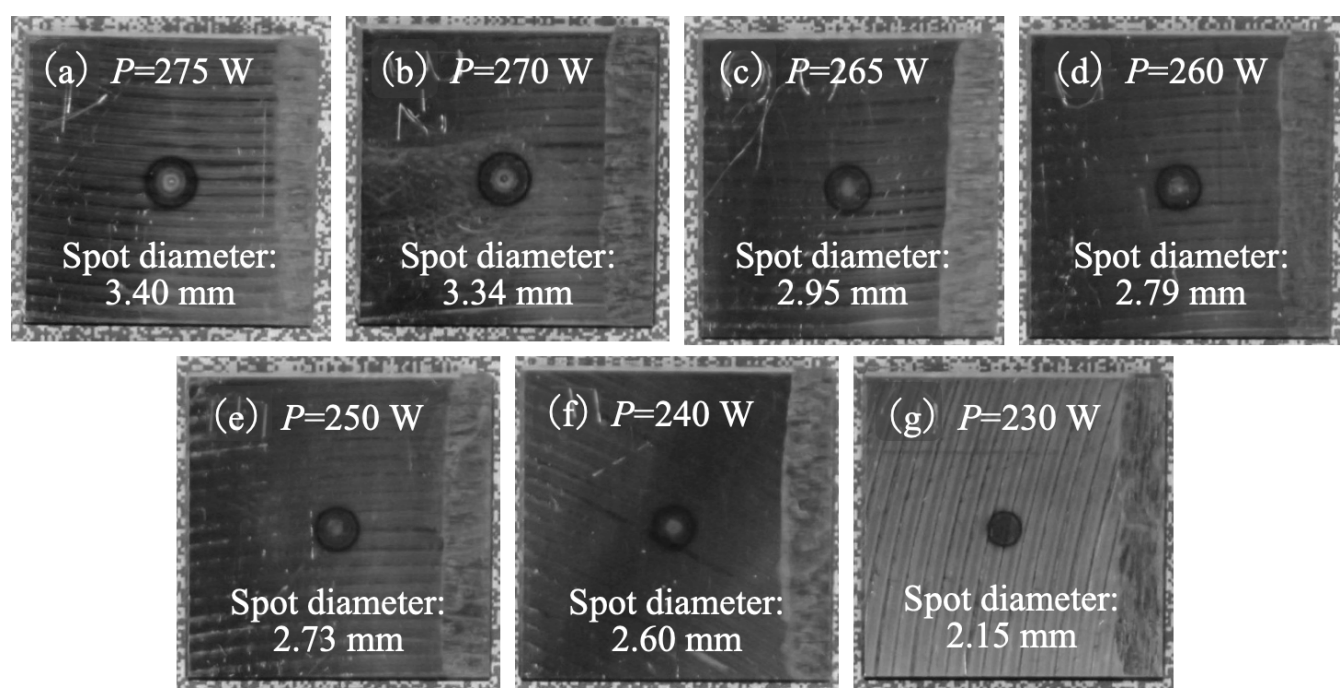

Fig. 5 Appearance of laser irradiated spot on upper surface of specimen. 

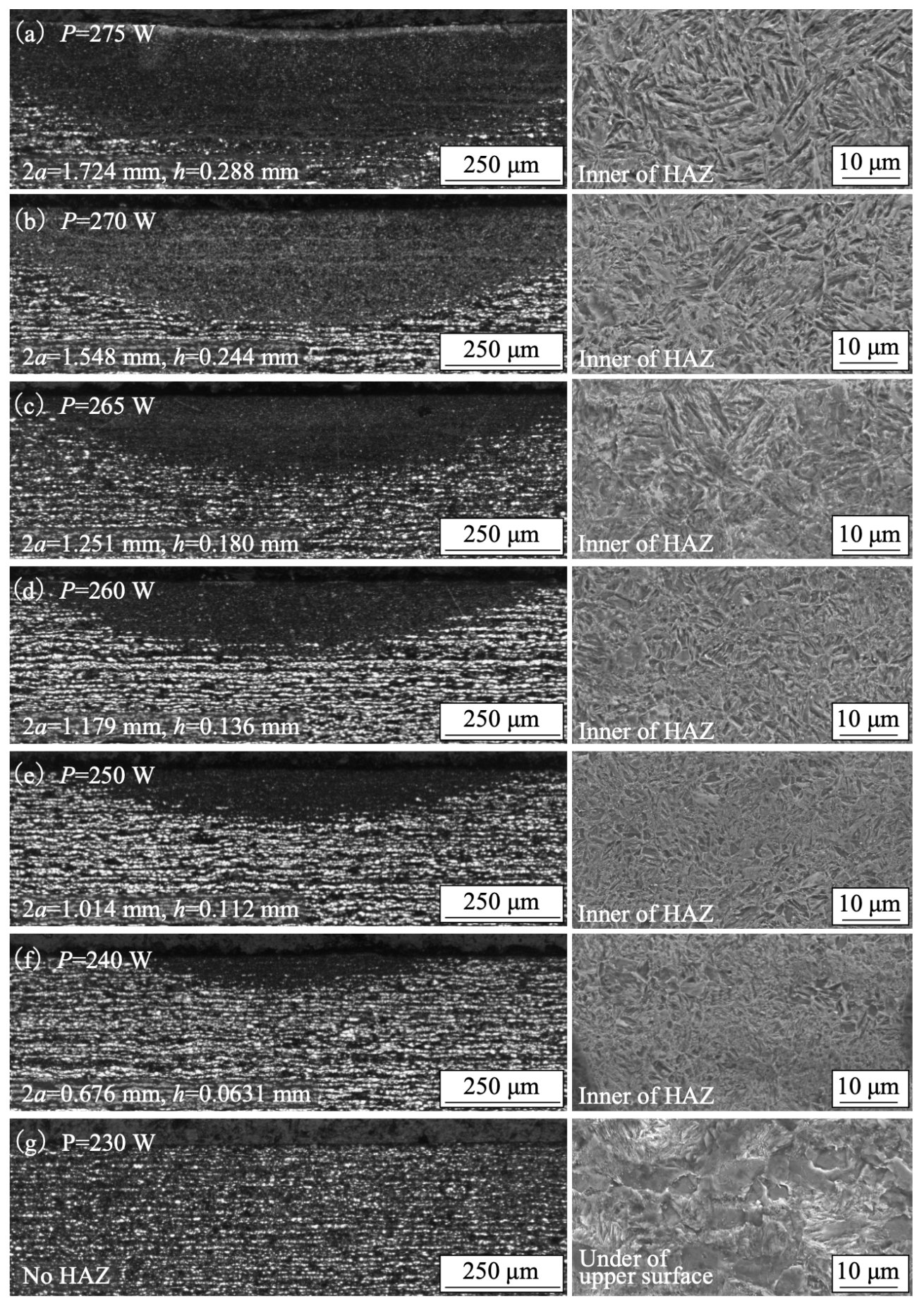

Fig. 6 Microscope and SEM observation of HAZ in vertical section of laser quenched specimen.

Table 3 Estimated volume of HAZ.

\begin{tabular}{ll}
\hline Laser power & Volume of HAZ, \\
$P / \mathrm{W}$ & $V / \mathrm{mm}^{3}$ \\
\hline 275 & 0.348 \\
270 & 0.237 \\
265 & 0.114 \\
260 & 0.0753 \\
250 & 0.0459 \\
240 & 0.0115 \\
\hline
\end{tabular}

Table 4 Vickers hardness of HAZ and outer HAZ.

\begin{tabular}{lll}
\hline Laser power & \multicolumn{2}{l}{ Vickers hardness, $H V / \mathrm{MPa}$} \\
$P / \mathrm{W}$ & HAZ & Outer HAZ \\
\hline 275 & 672 & 220 \\
270 & 643 & 201 \\
265 & 634 & 224 \\
260 & 656 & 195 \\
250 & 645 & 208 \\
240 & 529 & 222 \\
230 & 245 & 215 \\
\hline
\end{tabular}


た. 3.1 節において HAZ 外の領域および $230 \mathrm{~W}$ の試料から は, フェライト・パーライトが観察されていることを述べた が, ビッカース硬さは全て $H V=200 \mathrm{MPa}$ 程度であり, 改め て前述の組織であることを確認できた，HAZでは各レーザ 出力で $H V=500 \mathrm{MPa}$ 以上の硬度となっており, JIS G 0559： 鋼の炎焼入および高周波焼入硬化層深さ測定方法 ${ }^{13)}$ におい て指定されている有効硬化層の限界硬さ，炭素含有率 $0.33 \%$ 以上 $0.43 \%$ 未満の場合で $H V=400 \mathrm{MPa}$ ，あるいは炭素含有 率 $0.43 \%$ 以上 $0.53 \%$ 未満の場合で $H V=450 \mathrm{MPa}$ ，を満たし ている.よって，HAZではレーザ焼入れによるマルテンサ イト組織の生成ならびに硬化がなされたと考えられる.

\section{3 レーザ焼入れ実験中に検出された $\mathrm{AE}$ 波}

レーザ焼入れ実験中に検出された波形ついて, 代表例とし て Fig. 7 にレーザ出力 $275 \mathrm{~W}$ のもをを示す。レーザ照射開始

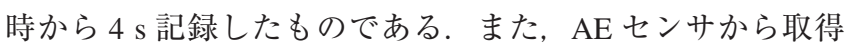
した波形に加え, Fig. 7 には矩形波状の信号も示している. これはレーザ ON および OFF を示す信号であり，縦軸と重 なって確認できないが $t=-3 \mathrm{~s}$ にレーザ照射開始の瞬間を示 す矩形波の立ち上がり，そして $t=0 \mathrm{~s}$ にてレーザ照射停止の 瞬間を示す矩形波の立ち下がりがある。このレーザ照射によ る加熱中の $3 \mathrm{~s}$ はノイズレベルよりも振幅の大きい連続型 $\mathrm{AE}$ が観察された。局所加熱による挙動であると考えられ
る。そして, $t=0 \mathrm{~s}$ のレーザ照射停止と同時にこの連続型 $\mathrm{AE}$ はなくなり, 焼入れ過程においてマルテンサイト変態の 情報を含むと思われる $\mathrm{AE}$ がおよそ $t=0.1 \mathrm{~s}$ をピークに発生 している，その後，AEはノイズレベルまで減少した.

Fig. 8 はレーザ照射停止の瞬間である $t=0 \mathrm{~s}$ から, $t=160$ $\mathrm{ms}$ までを抜き出した各レーザ出力の波形である. Fig. 7(出 力 $275 \mathrm{~W}$ の例)にて着目したおよそ $t=100 \mathrm{~ms}(0.1 \mathrm{~s})$ にピーク を有する $\mathrm{AE}$ の振幅が, レーザ出力の減少に伴ってノイズレ ベルへと近づき，出力 $230 \mathrm{~W}$ では確認できなくなった， 3.1 節にて示した HAZにおけるマルテンサイト組織生成や各 レーザ出力による体積の変化を踏まえると，レーザ出力が大

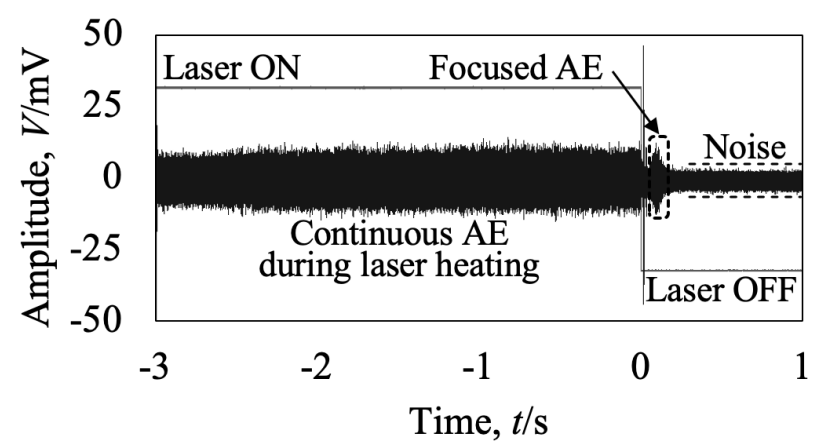

Fig. 7 Observed all wave during laser irradiation start to $1 \mathrm{~s}$ after from laser irradiation stop in the case of $275 \mathrm{~W}$ experiment.
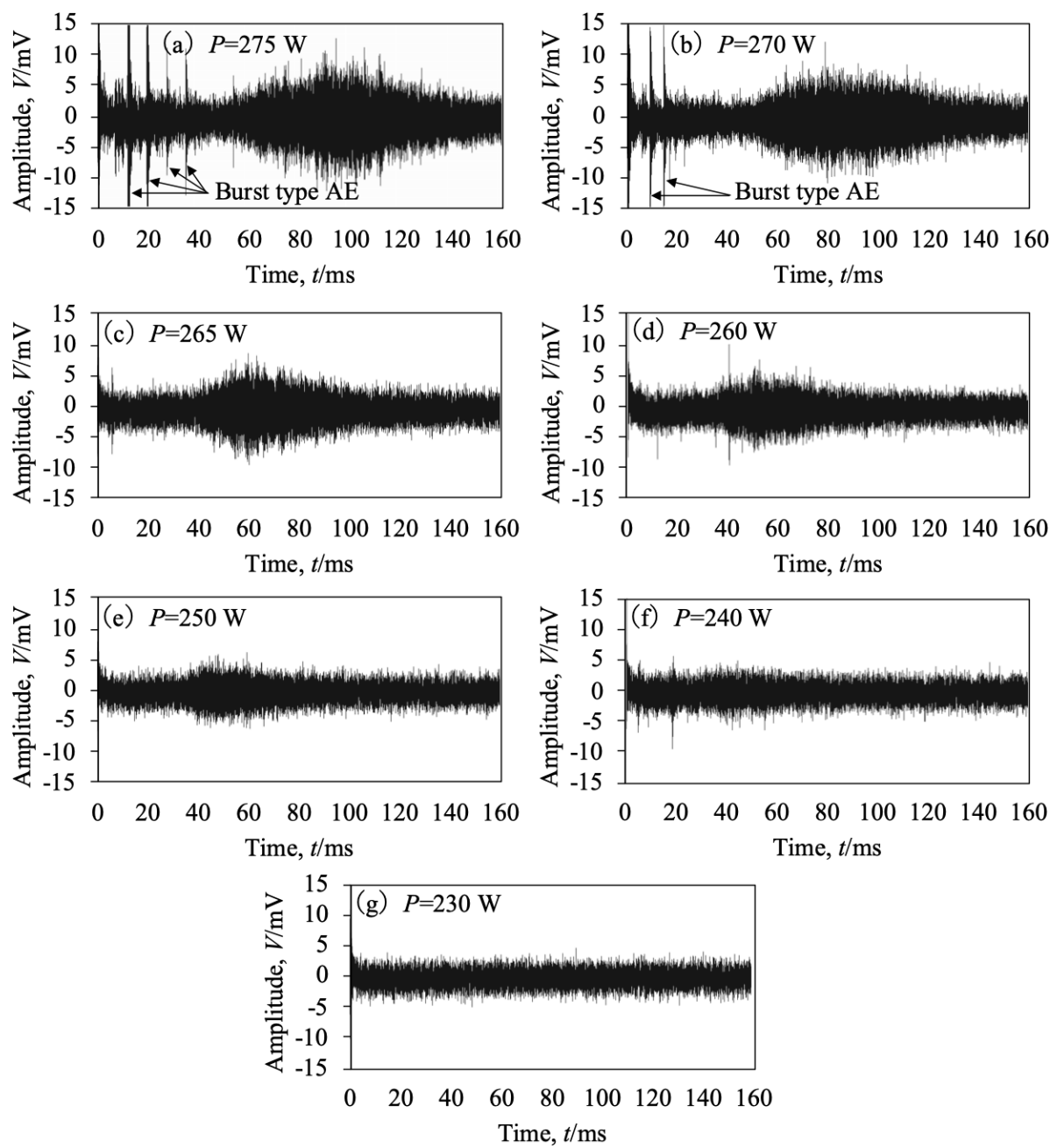

Fig. 8 Observed AE wave during quenching process, after laser irradiation stop. 
きいほどHAZ およびマルテンサイト組織の体積は大きく, $\mathrm{HAZ}$ 内でのマルテンサイト変態が $\mathrm{AE}$ 発生源であるため, これに AEの振幅が対応したと考えられる. Table 2 に記し たレーザ停止後 $\mathrm{M}_{\mathrm{s}}$ 点まで到達する推定時間と比較するとや や遅いが, HAZ 内部の組織観察から確認されたとおり実験 では解析よりも加熱されている可能性があり, それに応じて 冷却時間も長くなったことが考えられる. また, 出力 $275 \mathrm{~W}$ の場合 $t=100 \mathrm{~ms}$ であったピークの発生時間はレーザ出力の 減少に伴って早まっており, 出力 $240 \mathrm{~W}$ の場合はピーク発 生時間がおよそ $t=40 \mathrm{~ms}$ となっている.レーザ出力が大き いほど試料への入熱は大きく, その分, 焼入れ過程において $\mathrm{M}_{\mathrm{s}}$ 点への到達に時間を要するため, これが $\mathrm{AE}$ のピーク発 生時間の変化に現れたと考えられる. Table 2 の推定 $\mathrm{M}_{\mathrm{s}}$ 点到 達時間も同様な挙動である。今回の条件において最も遅かっ た出力 $275 \mathrm{~W}$ の場合でもレーザ照射停止以降 $100 \mathrm{~ms}$ には $\mathrm{AE}$ が発生しており, マルテンサイト変態が発生する冷却速 度としては十分と言える。

これらの $\mathrm{AE}$ とは別に, 出力 $275 \mathrm{~W} て ゙ は ~ t=40 \mathrm{~ms}$ 程度ま で, 出力 $270 \mathrm{~W} て ゙ は ~ t=20 \mathrm{~ms}$ 程度まで, 突発型 $\mathrm{AE}$ が目 立って検出されている. 出力 $265 \mathrm{~W}$ 以下ではこれが顕著で ない，あるいは明確に見られない．前述のレーザ出力および マルテンサイト組織の体積に伴って振幅が変化した $\mathrm{AE}$ とは 別の発生源に対応するものと考えられる. マルテンサイト変

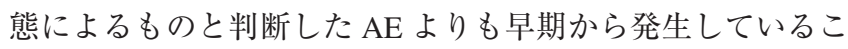
と, また, レーザ出力条件のなかでも高出力のもののみで発 生していることから, 加熱部に発生した熱澎張が, レーザ照 射停止後の冷却過程にて収縮に切り替わり，それによるエネ ルギー解放がこの突発型 $\mathrm{AE}$ 波の発生源となったと考えられ る。これについてはより詳細な調査が必要であるが, 例えば レーザ焼入れ工程中にマルテンサイト変態以外の意図せ女現 象が生じたことを知るための情報として活用できる可能性が ある。

\section{$3.4 \mathrm{AE}$ カウント累積数を参考とした AE の RMS 值の算出 と HAZ の体積との関係}

Fig. 9 は, Fig. 8 で示した各レーザ出力の波形に対してノ イズレベルにしきい值を設定し，しきい值を超えた AEの振 幅と AE カウントの累積数を経過時間に対してまとめたもの である、プロットはしきい值を超えた $\mathrm{AE} の$ 振幅, 実線は $\mathrm{AE}$ カウントの累積数を示している. $\mathrm{AE}$ カウントの合計数 は出力 $275 \mathrm{~W}$ のもを最大として, やはり出力が小さい, つまりマルテンサイト組織の体積が小さいほどその数が小さ くなった. 出力 $230 \mathrm{~W}$ の場合はレーザ照射停止時の $\mathrm{AE}$ が $\mathrm{AE}$ カウント合計数のほとんどを締め, 以降 $t=160 \mathrm{~ms}$ まで に発生したしきい值を超える AE は3つのみである.

Fig. 8 の波形の観察だけでは, マルテンサイト変態の開始 から終了までの $\mathrm{AE}$ の持続時間を判別しづらいため, Fig. 9 に示された $\mathrm{AE}$ カウント累積数が増加し始め, それが収束す るまでの推移を参考に $\mathrm{AE}$ の持続時間を判断した．例えば出 力 $275 \mathrm{~W}$ の場合, $\mathrm{AE}$ カウント累積数の増加が開始されよう とする $t=53.2 \mathrm{~ms}$ よりプロットの振幅も増大を開始し, 振幅 がノイズレベルに減少した $t=149.2 \mathrm{~ms}$ にて累積数も最大值
に向かって収束している，よって，出力 $275 \mathrm{~W}$ の場合はこ の時間帯の $\mathrm{AE}$ がマルテンサイト変態によるものであると判 断した. マルテンサイト組織の生成と AE が確認されなかっ た出力 $230 \mathrm{~W}$ の結果を除き, その他の結果についても同様 にマルテンサイト変態の開始から終了までの持続時間を判定 し，それぞれ判定した時間帯の $\mathrm{AE}$ について式(2)に基づき RMS 值を算出した。 そして，算出したRMS 值を HAZ，す なわちマルテンサイト組織の体積に対してまとめると Fig. 10 に示すようになった. 一点, 異なるプロット $(\boldsymbol{\Delta})$ がある が,これについては次節にて述べる。マルテンサイト組織の 体積と AEの RMS 值が線形に近い関係となったＡEの RMS 值は発生源のエネルギーを表すため, 妥当な結果が得 られたと言える。

以上の結果と見解から，レーザ焼入れ中に発生した AEを 観察および抽出し，これを RMS 值にまとめることによっ て，生成したマルテンサイト組織の体積を推定することがで きると言える。なお本研究では, $\mathrm{AE}$ 発生源すなわちマルテ ンサイト変態を生じた HAZの体積と, そこでのエネルギー に相関する RMS 值をパラメータとして結果をまとめている が, $\mathrm{AE}$ カウントの合計数やマルテンサイト変態を示す $\mathrm{AE}$ の持続時間についても, $\mathrm{AE}$ パラメータとしてマルテンサイ 卜組織生成に関する情報を含むものと考えられる.

\section{5 相当レーザ出カが不明となった試料の検討}

実験を進めるなかで，設定したレーザ出力に対して焼入れ 結果が正常でないと疑われる 1 件の事例が生じた.この試料 のスポット外観を Fig. 11 に示す。実験時はレーザ出力を $270 \mathrm{~W}$ と設定していたが, 試料上面のスポット直径の測定か ら Fig. 5 にある $270 \mathrm{~W}$ のものと比較して小さく, レーザ出力 $250 \mathrm{~W}$ のものに近い.この事例の原因としては, レーザ本体 の誤作動, レーザ制御系の誤作動, 人為的な誤操作，あるい は試料上面の部分的な光沢により生じたレーザの反射による 加熱不足などが考えられ, 相当レーザ出力が不明となった結 果と言わざるを得ない.このように偶然得られた試料につい ても, Fig. 12 のように試料縦断面内の HAZの観察および最 大幅 $2 a$, 最大深さ $h$ の測定による体積算出, そしてマイク ロビッカース硬さ試験を実施した結果, 針状のマルテンサイ 卜組織生成が確認され, 体積 $V=0.0440 \mathrm{~mm}^{3}$, ビッカース硬 さ $H V=577 \mathrm{MPa}$ となった．体積の值で判断すると，これは 本研究における実験条件において出力 $250 \mathrm{~W}$ の結果に近い 焼入れである言える.また，Fig. 13 に観察された AEを，そ して Fig. 14 に AE カウント累積数を示す.これらをもとに, 3.4 節と同様の方法によって RMS 值を算出すると, $V_{R M S}=$ $7.39 \mathrm{mV} \cdot \mathrm{ms}$ となり, $\mathrm{AE}$ の情報からも出力 $250 \mathrm{~W}$ に最も近 い焼入れであったと判定できた. 前節にて示した Fig. 10 に は, この相当レーザ出力が不明となった試料の RMS 值プ ロット $(\boldsymbol{\Delta})$ を含めている.

このような事例に対して, $\mathrm{AE}$ の観察からマルテンサイト 組織の体積推定が可能であることが示されたと考えられる. 

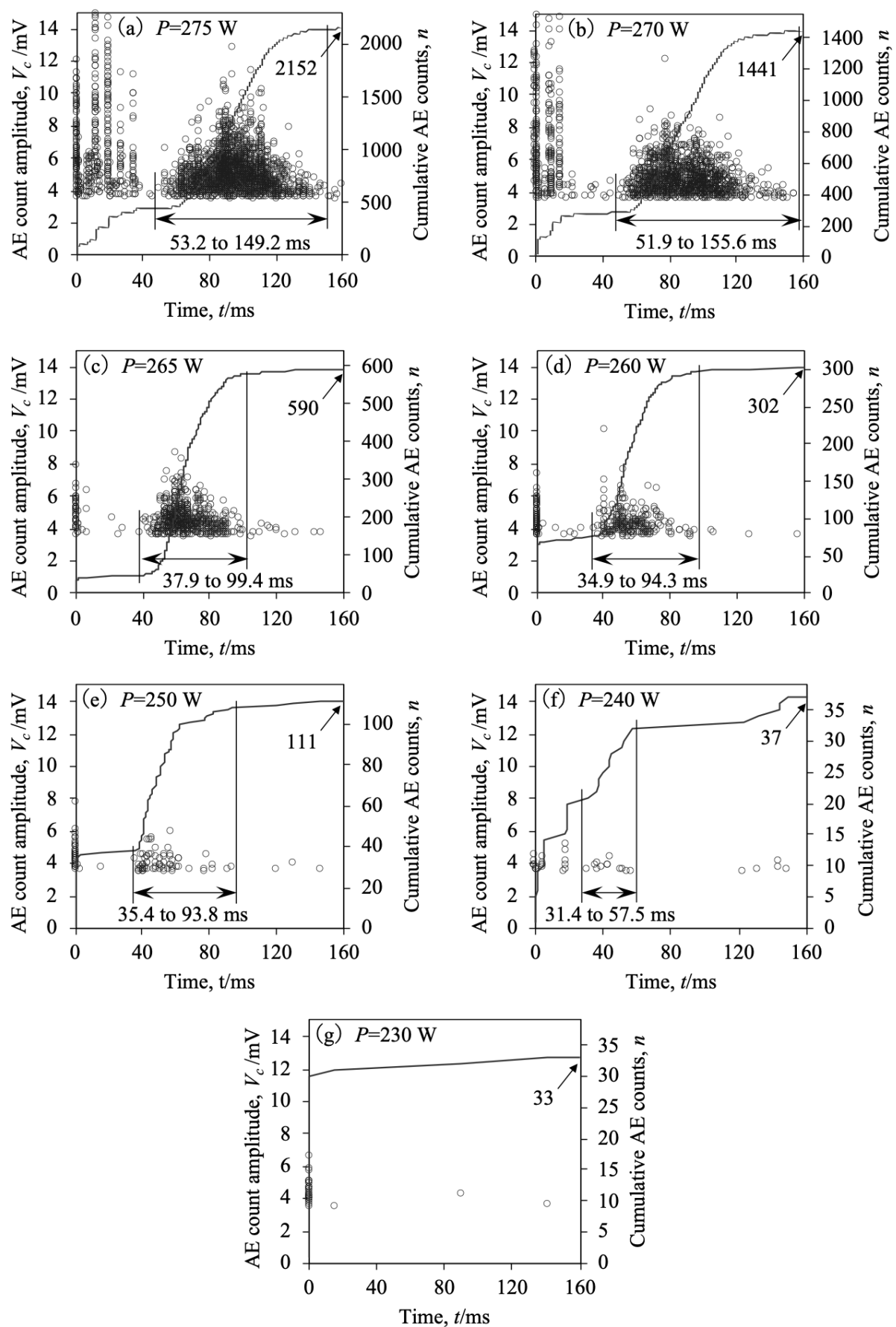

Fig. 9 AE amplitude over threshold at noise level and cumulative AE counts.

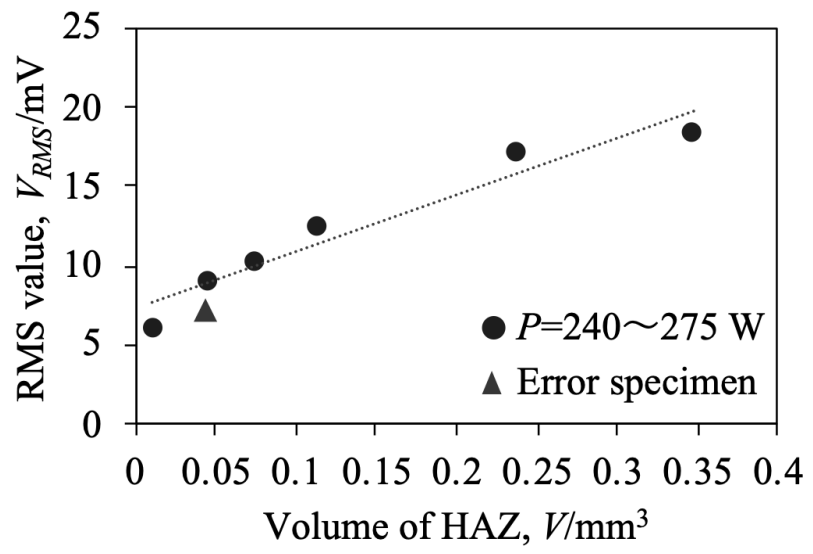

Fig. 10 Relationship between volume of HAZ and RMS value of AE wave.

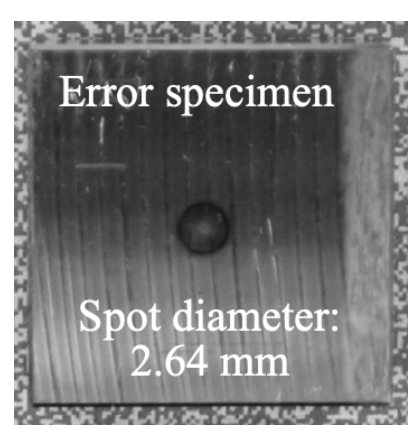

Fig. 11 Appearance of laser irradiated spot on upper surface of error specimen. 

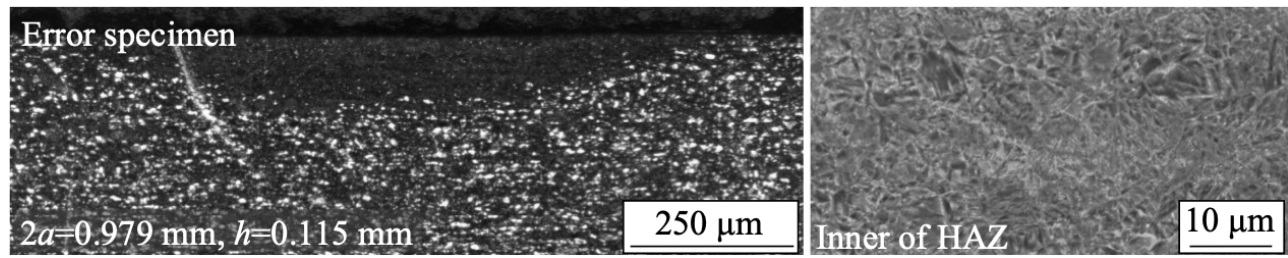

Fig. 12 Microscope and SEM observation of HAZ in vertical section of error specimen.

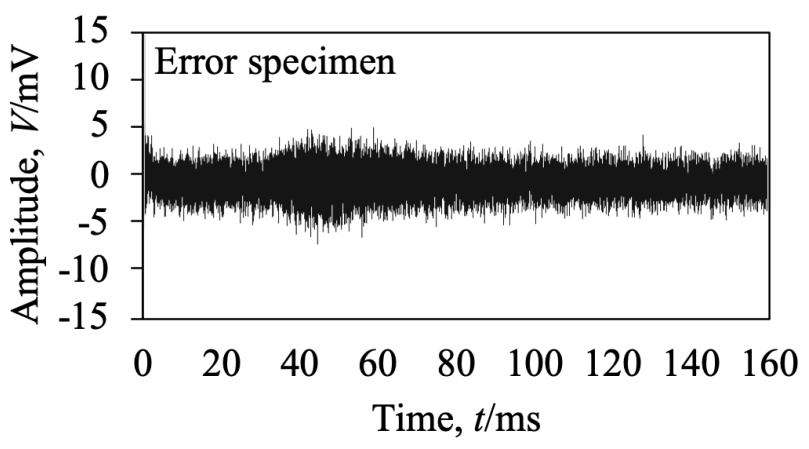

Fig. 13 Observed $\mathrm{AE}$ wave during quenching process, after laser irradiation stop in the case of error specimen.

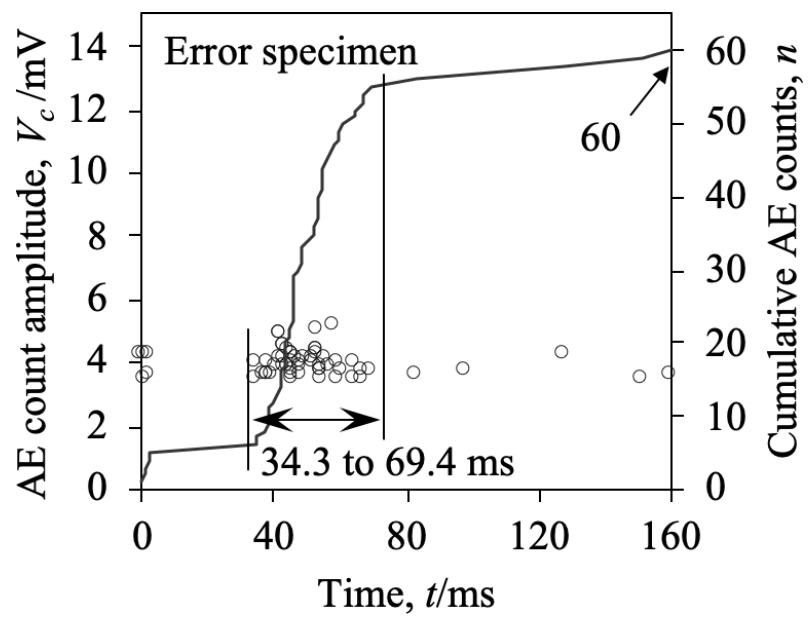

Fig. 14 AE amplitude over threshold at noise level and cumulative $\mathrm{AE}$ counts in the case of error specimen.

4. 結言

本研究では，SCM440 にファイバーレーザを用いた円形状 レーザ焼入れを施し，工程中のマルテンサイト変態に伴う $\mathrm{AE}$ を観察する実験を実施した。得られた結言を以下に記 す.

（1） 円形状レーザ焼入れ実験の結果, 球冠形状と考えら れる HAZ が生成し，組織観察およびマイクロビッカース硬 さ試験の結果から, その内部はマルテンサイト組織と確認さ れた。 なお，本研究において最小のレーザ出力条件である $230 \mathrm{~W}$ の場合, HAZ およびマルテンサイト組織の生成は確 認されなかった。
（2）レーザ焼入れ実験により生成したマルテンサイト組 織の推定体積を算出したところ, 実験条件であるレーザ出力 が大きいほど，体積も大きくなることが確認された．

（3）レーザ焼入れ実験中に検出された $\mathrm{AE}$ から，レーザ 照射停止以降の焼入れ過程において特徴が見られ，これは レーザ出力の減少, すなわち生成するマルテンサイト組織の 減少に伴って減少した。ノイズレベルにしきい值を設定して まとめた $\mathrm{AE}$ 振幅と $\mathrm{AE}$ カウント累積数を参考として，この 特徵ある部分の持続時間を判定し, この時間帯の $\mathrm{AE}$ につい て RMS 值を算出したところ，マルテンサイト組織の体積の 増大に対応して AEの RMS 值も増大する妥当な結果が得ら れた。

（4）相当レーザ出力が不明となった試料について，得ら れた $\mathrm{AE}$ の情報からマルテンサイト組織の体積を概ね推定で きた。

本研究は JSPS 科研費 JP19K05087 の助成を受けたもので あり,ここに深く感謝の意を表します。

文献

1) The Laser Society of Japan: Laser Handbook, (Ohmsha, Tokyo, 2005) VIII, Chapter 35.

2) H. Hagino and T. Yamaguchi: J. Vac. Soc. Jpn. 56 (2013) 315-321.

3) N. Iwata and N. Kato: Inspection Engineering 15-11 (2010) 76-79.

4) The Japanese Society for Non-Destructive Inspection: Acoustic emis sion testing -diagnostics of machines ${ }^{-}$, (The Japanese Society for Non-Destructive Inspection, Tokyo, 2014) pp. 1-5.

5) M. Ohtsu: Characteristics and Theory of Acoustic Emission, (Morikita Publishing, Tokyo, 2005) pp. 4-6.

6) M. Takuma, N. Shinke and K. Fujii: M \& M 2010 Strength of Materials Conference, (The Japan Society of Mechanical Engineers, 2010) pp. 421-423.

7) M. Takuma, N. Shinke, Y. Takahashi and N. Yamashita: 18th National Conference on Acoustic Emission, (The Japanese Society for NonDestructive Inspection, 2011) pp. 19-22.

8) S.M.C. van Bohemen, M.J.M. Hermans and G.D. Ouden: J. Phys. D 34 (2001) 3312-3317.

9) Japanese Industrial Standards Committee Database. Low-alloyed steels for machine structural use, JIS G 4053. https://www.jisc.go.jp/app/jis/general/GnrJISSearch.html, (Accessed 2020-05-27).

10) The Japan Institute of Metals and Materials: Metal data book, (Maruzen, Tokyo, 2004) p. 479.

11) H. Nakamura: Journal of the JIME 52 (2017) 303-308.

12) The Japanese Society for Non-Destructive Inspection: Acoustic emission testing -diagnostics of machines ${ }^{-}$, (The Japanese Society for Non-Destructive Inspection, Tokyo, 2014) pp. 225-226.

13) Japanese Industrial Standards Committee Database. Steeldetermination of case depth after flame hardening or induction hardening, JIS G 0559.

https://www.jisc.go.jp/app/jis/general/GnrJISSearch.html, (Accessed 2020-05-27). 